\title{
Soluble Microbial Products Removal Profile and Morphological Assessment of Submerged Ultrafiltration Membrane
}

\author{
Nadir Dizge, Gulfem Soydemir, Secil Bayar, Ahmet Karagunduz* and Bulent Keskinler
}

Gebze Institute of Technology, Department of Environmental Engineering, 41400, Gebze, Kocaeli, Turkey

\begin{abstract}
Performance of ultrafiltration membranes were investigated with submerged membrane in terms of removal of soluble microbial products (SMP) (as proteins and carbohydrates) and fouling mechanisms. Cellulose (UC) and polyethersulphone (UP) membranes with different molecular weight cut off (MWCO) $(5,10,30 \mathrm{kDa}$ for UC and 5, 10, 20 $\mathrm{kDa}$ for UP) were tested in the bioreactor. The quality of permeate was compared in terms of SMP and COD. There was no significant difference in the total SMP removal effectives for both the UC and UP membranes with different MWCO characteristics. However, UP membranes were relatively more effective in removing soluble carbohydrates, while UC membranes were more effective in removing soluble proteins. The submerged membrane bioreactor achieved organic removal efficiencies ranging from $98.1 \pm 0.2 \%$ to $99.2 \pm 0.3 \%$ based on the soluble COD levels. Analysis of the membrane performance data by resistances-in-series model indicated that cake fouling was the dominant membrane fouling mechanisms. Increasing the MWCO was resulted in higher membrane flux but lower SMP removal. Morphological examination of the membranes by SEM and AFM showed significant accumulation of organisms on the membrane surface.
\end{abstract}

Keywords: Submerged membrane bioreactor, ultrafiltration, membrane fouling, soluble microbial products (SMP).

\section{INTRODUCTION}

Submerged membrane bioreactors (SMBRs) for wastewater treatment and water reuse applications have received significant interest in recent years as they offer operational and design benefits by eliminating the need for a secondary settling tank, require smaller reactor volume, and decrease sludge volume and quantity. However, limited experience available on sludge characteristics in the SMBRs and sensitivity of system performance to operating conditions restricts their wider applications. Performance characteristics of submerged membrane bioreactors with micro and macro systems have been studied to evaluate the effect of operational parameters on sludge filterability and process performance [1, 2]. Physiological properties of sludge from SMBRs have also been studied in terms of extracellular polymeric substances [3-5], carbohydrates and proteins [6], and soluble microbial products $[7,8]$.

Membrane fouling is one of the major operational concerns of SMBRs. It is a growing research area to understand membrane performance in relation to system parameters. Extracellular polymeric substances (EPS) or soluble microbial products (SMP) are large molecular weight compounds that are released by bacteria. They consist of proteins, polysaccharides, lipopolysaccharides, lipoproteins or complex mixtures of these biopolymers with a variety of functional sites

*Address correspondence to this author at the Gebze Institute of Technology, Department of Environmental Engineering, 41400, Gebze, Kocaeli, Turkey; Tel: +90 (262) 60532 11; Fax: +90 (262) 60532 05;

E-mail: akaragunduz@gyte.edu.tr including carboxyl, amino and phosphate groups. In recent years, research on polymeric substances either in soluble or bound form has gained increasing interest [9]. However, the current understanding of membrane fouling mechanisms and membrane performance in relation operational parameters in SMBRs are still limited. EPS plays an integral part of the biofilm structure and development especially for attachment, detachment, mechanical strength, and protection against environmental stress factors. The bioadhesive characteristics of EPS alter the original surface properties rendering hydrophobic surfaces to become hydrophilic. Once the EPS deposit on surfaces, they can provide sources of nutrition for bacteria, and create the conditions necessary for bacterial attachment [10].

Ultrafiltration (UF) processes are able to separate the majority of particles and microorganisms from raw water, and considered as the alternative to conventional clarification and filtration units [11]. So far, numerous studies were carried out to investigate the causes, characteristics and mechanisms of MBR fouling, and to develop more efficient methods for membrane fouling mitigation [12, 13]. Different pretreatment processes to remove relevant foulants from treated wastewater have been investigated up to the present [14-19]. However, there is still little information available with regard to the impact of membrane type and material on MBR fouling, and thus further in-depth investigation is required.

The purpose of the study was to evaluate the performance of submerged membrane modules in a 
continuous bioreactor system in relation to removal of soluble microbial products (SMP) (as proteins and carbohydrates) and membrane fouling mechanisms. Cellulose (UC) and polyethersulphone (UP) membrane modules with different molecular weight cut off (MWCO) $(5,10,30 \mathrm{kDa}$ for UC and 5, 10, $20 \mathrm{kDa}$ for UP) were placed in the bioreactor operated with synthetic domestic wastewater. The quality of the effluent from the bioreactor was compared with the quality of the filtrates for SMP and COD. Membrane fouling mechanisms were analyzed by resistances in series model. Morphological assessments were performed by scanning electron microscopy (SEM) and atomic force microscopy (AFM).

\section{MATERIALS AND METHODS}

\subsection{Submerged Membrane Bioreactor}

A submerged membrane bioreactor (SMBR) with an effective volume of $50 \mathrm{~L}$ was used to treat the synthetic municipal wastewater [20]. The MBR system was operated with synthetic wastewater to control the operating conditions and evaluate the system performance in a systematic manner. The synthetic wastewater composition was given in our previous study [20]. All reagents were of analytical grade. The seed sludge was obtained from the sedimentation tank of Gebze Wastewater Treatment Plant in Turkey.

Influent and returned sludge were fed to the bioreactor with a peristaltic pump (Cole Parmer
Masterflex) and a diaphragm dosaging pump, respectively. Compressed air was supplied by a peripheral diffuser which was placed at the base of the bioreactor. The air supplied by the diffuser provided mixing of suspension in the bioreactor and scouring of the membrane surface. The dissolved oxygen concentration in the bioreactor was $4.6 \pm 1.1 \mathrm{mg} / \mathrm{L}$. The hydraulic retention time (HRT) was kept at $12 \mathrm{~h}$, and sludge retention time (SRT) was 10 days. Excess sludge was withdrawn daily at a rate of $5 \mathrm{~L} /$ day from of the bioreactor to maintain the concentration of MLSS at $3394 \pm 254 \mathrm{mg} / \mathrm{L}$ at 10 days. The sludge temperature was controlled at $22.4 \pm 1.9{ }^{\circ} \mathrm{C}$ with an electric heater. Detailed operational conditions of the bioreactor system are summarized in Table 1. After 60 days, the bioreactor operation was terminated and the supernatant was analyzed.

The flat sheet membrane modules, made of polypropylene, had a total area of $50 \mathrm{~cm}^{2}$ each. The modules were operated under constant suction pressure $(-140 \pm 5 \mathrm{mmHg})$ and the membrane flux was monitored by measuring the amount of filtrate produced over time. Each filtration run was conducted for $24 \mathrm{~h}$.

\subsection{Membrane Characteristics}

Cellulose (UC) and polyethersulfone (UP) ultrafiltration membranes by Microdyne Nadir, Germany were used in this study. Three types of cellulose (UC) membranes with MWCO of $5,10,30 \mathrm{kDa}$ and three types of polyethersulfone (UP) membranes with MWCO of 5, 10, $20 \mathrm{kDa}$ were used. Three membrane

Table 1: Operating Conditions of Bioreactor and Submerged Membrane Modules

\begin{tabular}{|c|c|c|}
\hline System parameters & Value & Unit \\
\hline \multicolumn{3}{|l|}{ Influent } \\
\hline COD & $610 \pm 52$ & $\mathrm{mg} / \mathrm{L}$ \\
\hline $\mathrm{BOD}_{5}$ & $450 \pm 40$ & $\mathrm{mg} / \mathrm{L}$ \\
\hline \multicolumn{3}{|l|}{ Bioreactor } \\
\hline Bioreactor volume & 50 & L \\
\hline Sludge retention time (SRT) & 10 & $d$ \\
\hline Hydraulic retention time (HRT) & 12 & $\mathrm{~h}$ \\
\hline Hydraulic flow rate & 100 & $\mathrm{~L} / \mathrm{d}$ \\
\hline F/M ratio & 0.36 & $1 / d$ \\
\hline MLSS concentration & $3394 \pm 254$ & $\mathrm{mg} / \mathrm{L}$ \\
\hline MLVSS concentration & $3061 \pm 235$ & $\mathrm{mg} / \mathrm{L}$ \\
\hline Organic loading rate (OLR) & 1.3 & $\mathrm{~kg} \mathrm{COD} / \mathrm{m}^{3} \mathrm{~d}$ \\
\hline Temperature & $22.4 \pm 1.9$ & ${ }^{\circ} \mathrm{C}$ \\
\hline Dissolved oxygen (DO) & $4.6 \pm 1.1$ & $\mathrm{mg} / \mathrm{L}$ \\
\hline $\mathrm{pH}$ & $7.3 \pm 0.2$ & - \\
\hline Specific air demand based on membrane area $\left(S A D_{m}\right)$ & 0.6 & $\mathrm{~m}^{3}$ air $/ \mathrm{m}^{2}$ membrane area $/ \mathrm{h}$ \\
\hline
\end{tabular}


modules were placed in parallel mode inside the bioreactor. The pressure inside the vacuum tank was measured with a vacuum pressure gauge $(0-1$ bar). The permeate quantities were measured in real time with an electronic balance (Schimadzu, Japan) and data were recorded on a RS 232 and $\mathrm{PCl}$ card.

\subsection{Membrane Resistance Analysis}

Membrane resistances were evaluated by the resistance-in-series model as follows (Eq. 1):

$$
R_{t}=R_{m}+R_{p}+R_{c}=\frac{\Delta P}{\mu . J}
$$

At the end of each run, the extent of membrane fouling was quantified by measuring permeate flux at constant suction pressure $(-140 \pm 5 \mathrm{mmHg})$. The membrane resistances were determined from the flux data given in our previous study [21]

\subsection{Physico-Chemical Analysis}

Measurements of chemical oxygen demand (COD), biochemical oxygen demand $\left(\mathrm{BOD}_{5}\right)$, mixed liquor suspended solids (MLSS), mixed liquor volatile suspended solids (MLVSS), and sludge volume index (SVI) were performed according to procedures described in APHA Standard Methods [22]. Samples for soluble COD were obtained by filtration of the mixed liquor through filter paper (cellulose acetate) with mean pore size of $0.45 \mu \mathrm{m}$. The $\mathrm{pH}$ measurements were carried out with a glass electrode (WTW multi 340i model $\mathrm{pH}$ meter, Multi Parameter Instrument). DO concentration and temperature in the bioreactor were measured by a DO meter (HACH HQ 40d multi).

The EPS were extracted using formaldehyde$\mathrm{NaOH}$ extraction method in accordance with Li's et al. [23]. The measurement of protein content was carried out according to Lowry methods [24]. BSA was used as a standard and the results expressed in mg equivalent of bovine serum albumin (BSA) per liter. Polysaccharides were determined the phenol-sulfuric acid method of Dubois et al. [25]. Glucose was used as a standart and the results expressed in $\mathrm{mg}$ equivalent of glucose per liter. All samples were determined the concentrations using a UV-vis spectrophotometer (GBC-Cintra-20) at the wavelength of $660 \mathrm{~nm}$ for protein or at the wavelength of $490 \mathrm{~nm}$ for polysaccharide.

Membranes were examined by a scanning electron microscope (SEM) (Philips XL30 SFEG Scanning
Electron Microscopy) before and after the filtration runs. For SEM analyses, a small membrane sample $(0.5 \times 0.5 \mathrm{~cm})$ was used. The membrane samples were fixed with $3.0 \%$ glutaraldehyde in $0.1 \mathrm{M}$ phosphate buffer at $\mathrm{pH} 7.2$, dehydrated with ethanol (95\%), and dried at room temperature. The samples were gold coated prior to examination by SEM.

Atomic force microscopy (AFM, Digital Instruments) was used to examine the surface morphology of the membranes. Before AFM observations, both the used and clean membranes were gently washed with deionized water and dried at room temperature. The membrane samples were fixed on glass slides and scanned over $10.0 \mu \mathrm{m} \times 10.0 \mu \mathrm{m}$. AFM was performed in tapping mode at a scanning rate of $6.104 \mathrm{~Hz}$. The images were analyzed using Nanoscope 3.0 software.

\section{RESULTS AND DISCUSSION}

\subsection{SMP and COD Removal}

Effectiveness of UF membranes with different MWCO were evaluated for SMP removal as total $\left(S P_{t}\right)$, carbohydrate $\left(S_{M P}\right)$, and protein $\left(S M P_{p}\right)$. The SMP levels in the filtrates were evaluated for protein and carbohydrate fractions and compared with those in the effluent from the bioreactor. Figure 1 presents a comparison of the SMP concentrations in the filtrate collected from each membrane and compares with those in the effluent from the bioreactor. The $\mathrm{SMP}_{t}$ levels in the filtrates ranged from 4.70 to $8.05 \mathrm{mg} / \mathrm{L}$ which was significantly less than the $\mathrm{SMP}_{\mathrm{t}}$ in the bioreactor effluent $(21.09 \mathrm{mg} / \mathrm{L})$. There was no significant difference in the removal effectives of $S_{M P}$ for both the UC and UP membranes with different MWCO characteristics. In addition, there was no significant difference in $\mathrm{SMP}_{\mathrm{t}}$ removal between the UP membranes and UC membranes. However, the UP membranes were relatively more effective in removing soluble carbohydrates while UC membranes were relatively more effective in removing soluble carbohydrates. The soluble carbohydrate levels in the filtrates for the UP membranes ranged from 1.12 to $1.75 \mathrm{mg} / \mathrm{L}$ and for the UC membranes they were between 3.97 and $4.02 \mathrm{mg} / \mathrm{L}$. The soluble protein levels in the filtrates for the UC membranes ranged from 0.87 to $1.22 \mathrm{mg} / \mathrm{L}$ and for the UP membranes it ranged from 2.95 to $6.93 \mathrm{mg} / \mathrm{L}$. Filtration performances and fouling behaviours of polyacrylonitrile (PAN) and polyvinylidene fluoride (PVDF) membranes were studied in a pilot-scale membrane bioreactor by Wang et al. [26]. Results showed that removable fouling was 


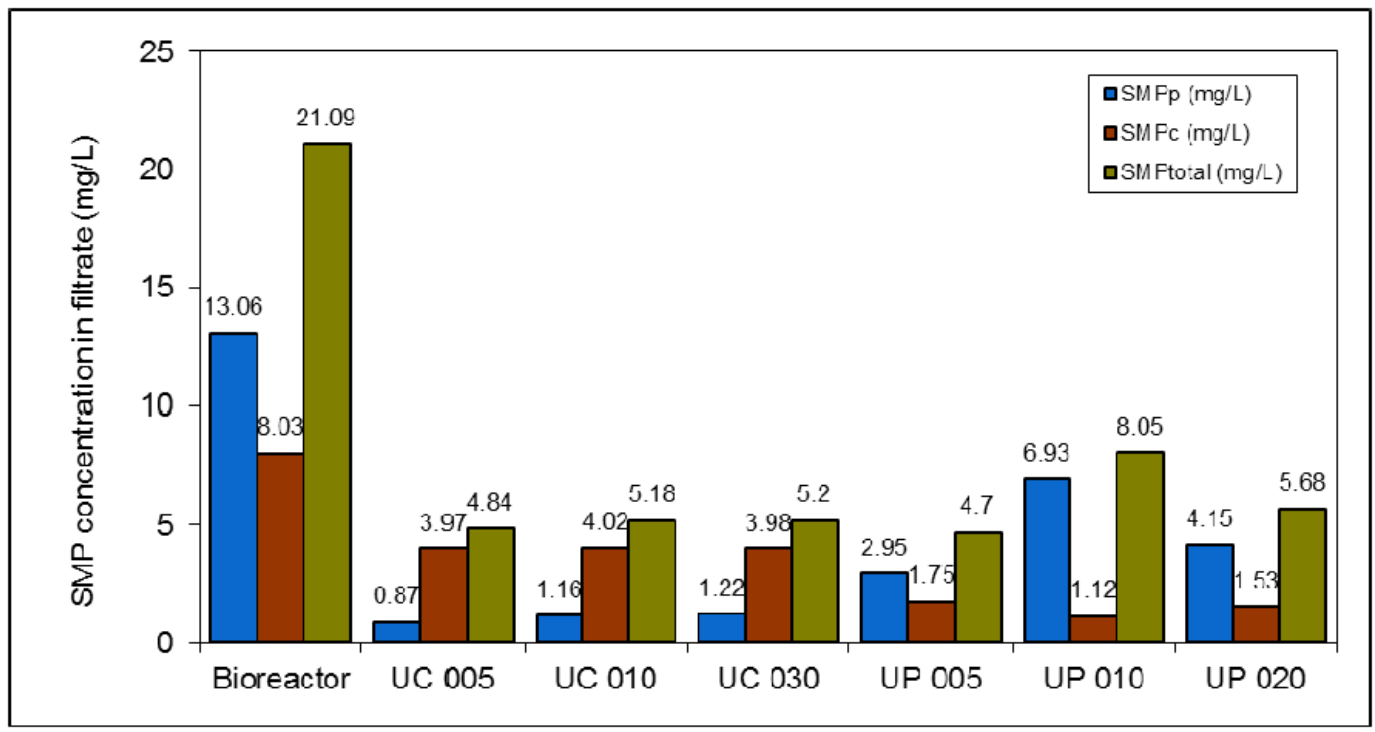

Figure 1: SMP levels in the bioreactor effluent and filtrates from SMBR.

dominant for both membranes while irremovable fouling of the PVDF membrane was severer than that of the PAN membrane. The PAN membrane could reject more soluble microbial products (SMP) than the PVDF membrane due to different pore sizes. The PVDF membrane rejected more carbohydrates and fewer proteins than the PAN membrane. The mean particle size of surface foulants on the PAN membrane was smaller than that on the PVDF membrane [26].

Influent COD to the bioreactor was $610 \pm 52 \mathrm{mg} / \mathrm{L}$, whereas effluent COD from the CASP system was about $64 \pm 19 \mathrm{mg} / \mathrm{L}$ and COD levels of the permeates from the SMBR were less than $11 \mathrm{mg} / \mathrm{L}$ for all the membranes tested. The COD removal from supernatant was primarily due to biological degredation in the bioreactor while COD removal in the permeates were due to membrane filtration and biofilm (biofouling layer) on the membrane surfaces [27].

\subsection{Membrane Resistance Profiles}

The values of $R_{m}, R_{p}$ and $R_{c}$ and their relative percentages in $R_{t}$ for submerged membrane process are presented in Table 2. UP 005 and UC 005 membranes had higher $R_{t}$ values which were $13.52 \times 10^{12} \mathrm{~m}^{-1}$ and $11.55 \times 10^{12} \mathrm{~m}^{-1}$ than the other membranes. When the resistances compared for UP and UC, UC membranes had the greatest cake resistance except of UC $005\left(9.25 \times 10^{12} \mathrm{~m}^{-1}, 6.23 \times 10^{12}\right.$ $\mathrm{m}^{-1}$, and $4.92 \times 10^{12} \mathrm{~m}^{-1}$, respectively). However, UC 010 had greatest pore resistance $\left(0.41 \times 10^{12} \mathrm{~m}^{-1}\right)$

Table 2: Estimated Resistances Due to Membrane $\left(\mathbf{R}_{\mathrm{m}}\right)$, Pore Blockage $\left(\mathbf{R}_{\mathrm{p}}\right)$, Cake Formation $\left(\mathbf{R}_{\mathrm{p}}\right)$ and Total Resistance $\left(\mathbf{R}_{\mathrm{t}}\right)$

\begin{tabular}{|c|c|c|c|c|}
\hline $\begin{array}{c}\text { Membrane } \\
\text { type }\end{array}$ & $\begin{array}{c}R_{t}\left(\times 10^{12}\right) \\
\left(m^{-1}\right)\end{array}$ & $\begin{array}{c}R_{m}\left(\times 10^{12}\right) \\
\left(m^{-1}\right) \\
(\%)\end{array}$ & $\begin{array}{c}R_{p}\left(\times 10^{12}\right) \\
\left(m^{-1}\right) \\
(\%)\end{array}$ & $\begin{array}{c}R_{c}\left(\times 10^{12}\right) \\
\left(\mathrm{m}^{-1}\right) \\
(\%)\end{array}$ \\
\hline UC 005 & 11.55 & $\begin{array}{c}1.92 \\
(16.6)\end{array}$ & $\begin{array}{l}0.38 \\
(3.3)\end{array}$ & $\begin{array}{c}9.25 \\
(80.1)\end{array}$ \\
\hline UC 010 & 6.80 & $\begin{array}{l}0.16 \\
(2.4)\end{array}$ & $\begin{array}{l}0.41 \\
(6.0)\end{array}$ & $\begin{array}{c}6.23 \\
(91.6)\end{array}$ \\
\hline UC 030 & 6.36 & $\begin{array}{c}1.15 \\
(18.1)\end{array}$ & $\begin{array}{l}0.29 \\
(4.5)\end{array}$ & $\begin{array}{c}4.92 \\
(77.4)\end{array}$ \\
\hline UP 005 & 13.52 & $\begin{array}{c}1.44 \\
(10.6)\end{array}$ & $\begin{array}{l}0.48 \\
(3.5)\end{array}$ & $\begin{array}{l}11.60 \\
(85.8)\end{array}$ \\
\hline UP 010 & 5.99 & $\begin{array}{l}0.16 \\
(2.7)\end{array}$ & $\begin{array}{l}0.56 \\
(9.3)\end{array}$ & $\begin{array}{c}5.27 \\
(88.0)\end{array}$ \\
\hline UP 020 & 4.87 & $\begin{array}{c}0.96 \\
(19.7)\end{array}$ & $\begin{array}{l}0.19 \\
(3.9)\end{array}$ & $\begin{array}{c}3.72 \\
(76.4)\end{array}$ \\
\hline
\end{tabular}


compare to the others. Similar trend was observed for UP membranes in cake $\left(11.60 \times 10^{12} \mathrm{~m}^{-1}, 5.27 \times 10^{12} \mathrm{~m}^{-1}\right.$, and $3.72 \times 10^{12} \mathrm{~m}^{-1}$, respectively) and pore resistances $\left(0.56 \times 10^{12} \mathrm{~m}^{-1}\right)$. For submerged membrane process, cake resistance had bigger values than pore resistance. This can be attributed to that as the pore size decreased the larger microbial aggregates could not pass through the surface pores of the membranes. However, the membranes with larger pore sizes (UC 010 and UP 010), the pore blockage resistance was estimated to be higher than the membrane resistance, indicating that some larger particles (or molecules) could enter the membrane matrix but could not to move through it. Increase in $R_{c}$ was a result of accumulation of soluble fraction of microbial products (carbohydrate and protein) on the membrane surface.

\subsection{Flux Analysis of the UF Membranes}

The flux values of submerged membrane process for UC and UP membranes with various MWCO are shown in Figure 2 as a function of the time. The initial and pseudo steady-state flux values for each membrane are also presented in Table $\mathbf{3}$. Initial sharp

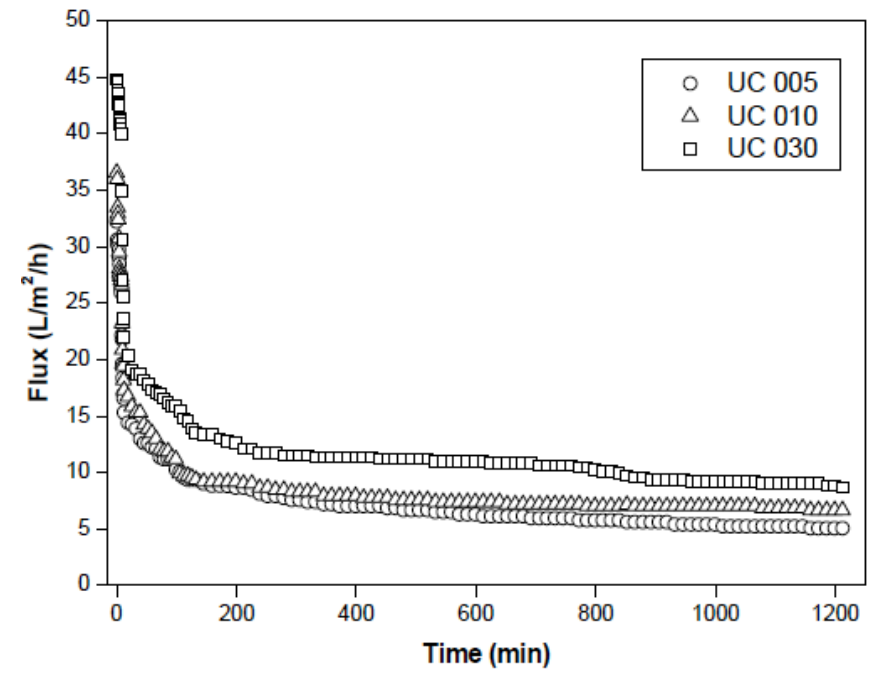

drop occurred for all the ultrafiltration membranes in the permeate flux within first twenty minutes. The flux gradually reduced after the initial drop and reached a pseudo steady state condition within 1,200 min. Steady state permeate flux values for UC with MWCO 5, 10, $30 \mathrm{kDa}$ were 5,7 and $9 \mathrm{~L} / \mathrm{m}^{2} / \mathrm{h}$, respectively. However, steady state permeate flux values for UP with MWCO $5,10,20 \mathrm{kDa}$ were 4,10 and $12 \mathrm{~L} / \mathrm{m}^{2} / \mathrm{h}$, respectively (Table 3). UP $20 \mathrm{kDa}$ membrane yielded the greatest steady state flux value followed by UP $10 \mathrm{kDa}$, UC 30 $\mathrm{kDa}$ and UC $10 \mathrm{kDa}$, while UC and UP $5 \mathrm{kDa}$ membranes had the lowest steady state flux value. The difference between UC and UP $5 \mathrm{kDa}$ membranes was relatively less (UP $020>$ UP $010>$ UP 005 and UC 030 $>$ UC $010>$ UC 005). However, the greatest steadystate flux of UP 020 when compared the type of membrane material can be explained as a result of lowest contact angle after the filtration (Table 4). The critical flux and chemical cleaning-in-place (CIP) in a long-term operation of a pilot-scale submerged membrane bioreactor for municipal wastewater treatment were investigated by Wei et al. [28]. It was reported that the analyses from fourier transform infrared spectrometry (FTIR) with attenuated total

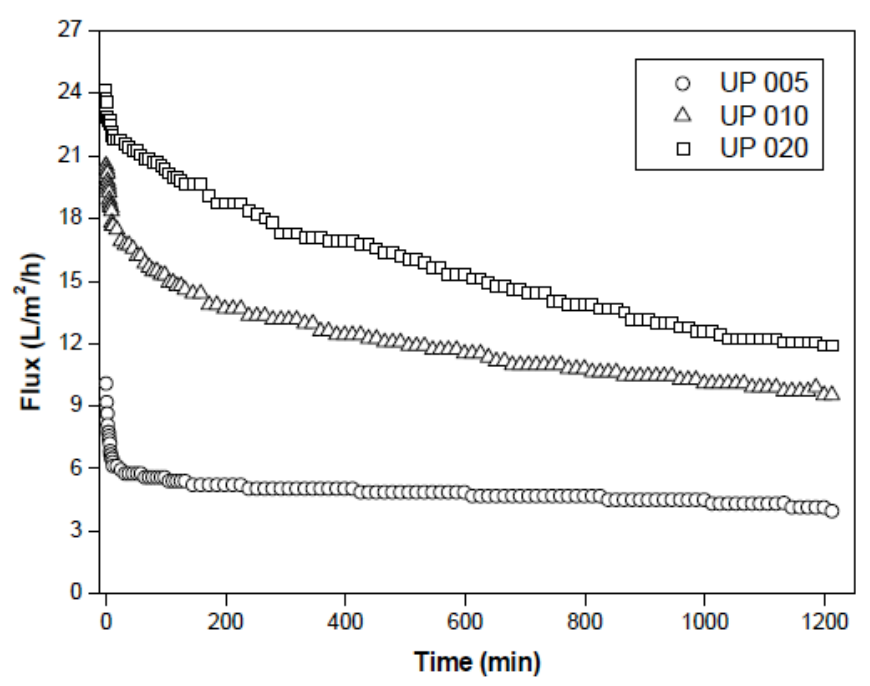

Figure 2: Variation of fluxes with time at different membranes with a different MWCO.

Table 3: Values of Initial and Steady-State Flux for Different UF Membranes

\begin{tabular}{|c|c|c|}
\hline Membrane type & $\begin{array}{c}\text { Initial flux }\left(\mathbf{J}_{\mathbf{o}}\right) \\
\left(\mathbf{L} / \mathbf{m}^{2} / \mathbf{h}\right)\end{array}$ & $\begin{array}{c}\text { Steady-state flux (J) } \\
\left(\mathbf{L} / \mathbf{m}^{2} / \mathbf{h}\right)\end{array}$ \\
\hline \hline UC 005 & 32 & 5 \\
UC 010 & 37 & 9 \\
UC 030 & 45 & 4 \\
UP 005 & 20 & 10 \\
UP 010 & 21 & 12 \\
UP 020 & 24 & \\
\hline
\end{tabular}


Table 4: Contact Angle Values of Unfouled and Fouled Membranes

\begin{tabular}{|c|c|c|}
\hline Membrane type & Unfouled membranes & Fouled membranes \\
\hline \hline UC 005 & $10<$ & 31 \\
UC 010 & $10<$ & 54 \\
UC 030 & $10<$ & 57 \\
UP 005 & 57 & 38 \\
UP 010 & 45 & 47 \\
UP 020 & 38 & 29 \\
\hline
\end{tabular}

reflectance accessory (ATR) and energy dispersive spectrometer (EDS) demonstrated that protein-like macromolecular organics and inorganics were the important components of the fouling layer [28].

\subsection{Morphological Characteristics}

The surface roughness is an important parameter for membrane studies and it may influnce the degree to which the foulants interact with membrane surface [29].
The AFM images of unfouled (Figure 3a-b) and fouled (Figure 3c-d) UC 010 and UP 010 membranes for submerged membrane process are presented in Figure 3a-d, respectively. Significant changes in surface morphology were observed for both types of membranes. The mean roughness $\left(R_{a}\right)$ of membrane surface are presented in Table 5 . The mean roughness of the UC membranes with MWCO increased by about 10 fold. For the UP membranes, the rougness increased by over 20 fold.

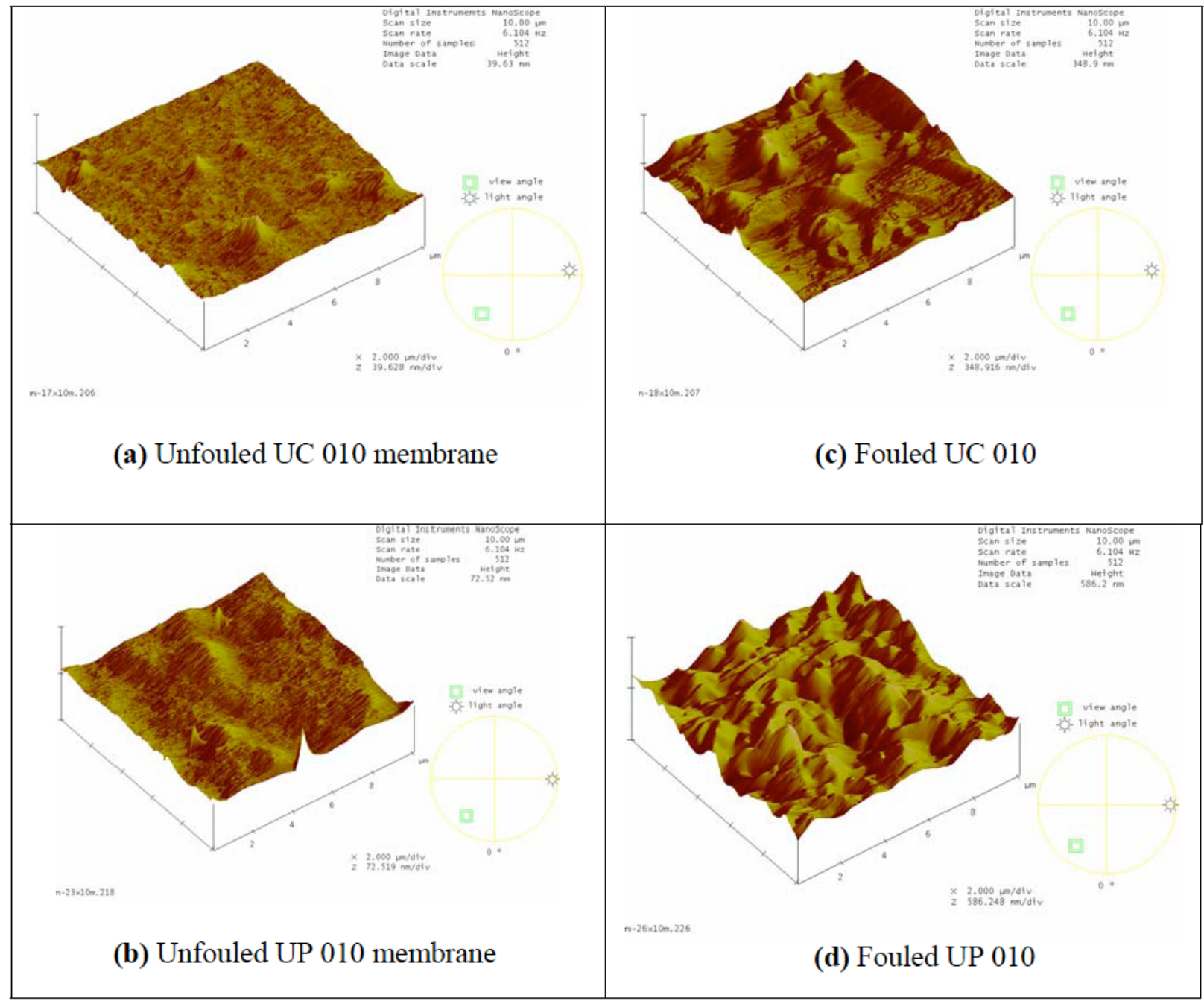

Figure 3: AFM images of the unfouled (a-b) and fouled (c-d) UC and UP membranes. 
Table 5: Mean Roughness $\left(R_{a}\right)$ of Unfouled and Fouled Membranes as Determined by AFM (Scanning of $10.0 \mu \mathrm{m} \times 10.0$ $\mu \mathrm{m}$ Area)

\begin{tabular}{|c|c|c|}
\hline Membrane type & Unfouled membranes & Fouled membranes \\
\hline \hline UC 005 & 2.02 & 29.74 \\
UC 010 & 1.17 & 10.01 \\
UC 030 & 4.84 & 55.12 \\
UP 005 & 1.64 & 52.71 \\
UP 010 & 2.09 & 30.76 \\
UP 020 & 1.51 & 32.59 \\
\hline
\end{tabular}

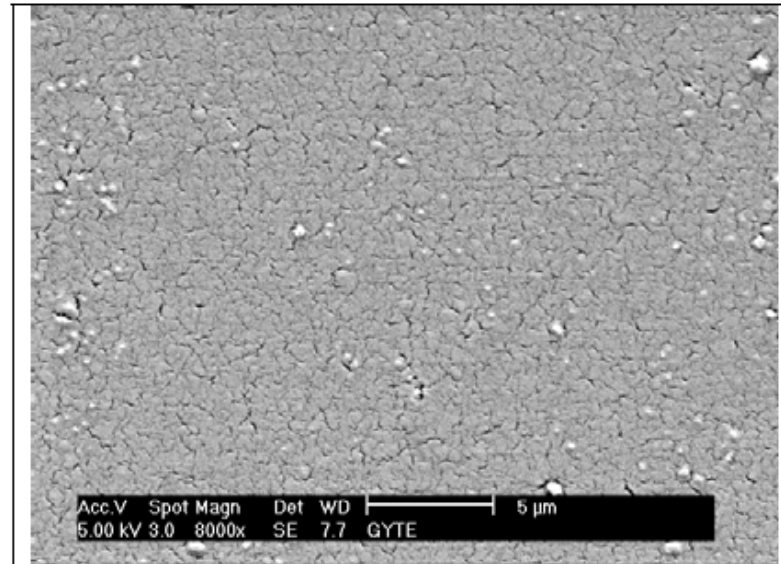

(a) Unfouled UC 005 membrane

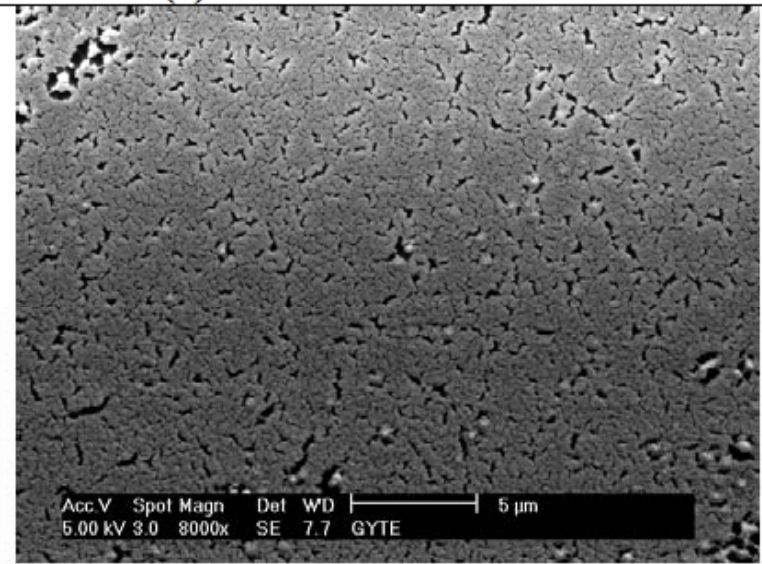

(b) Unfouled UC 010 membrane

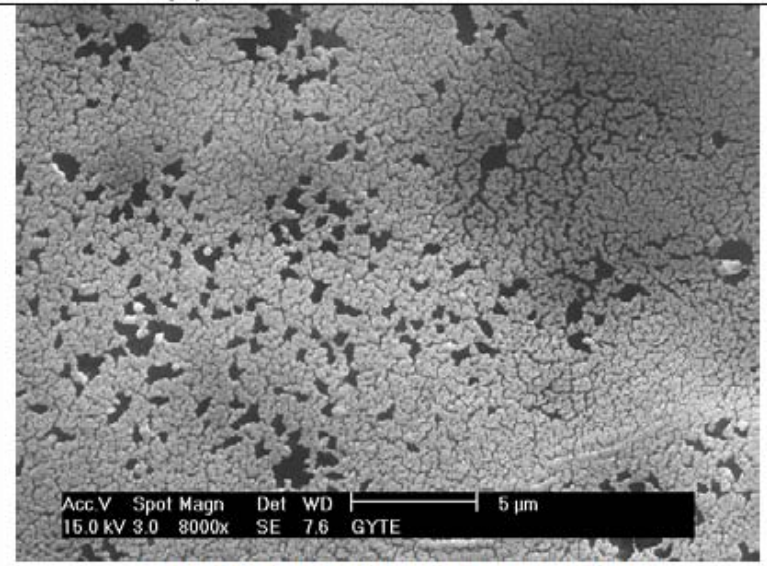

(c) Unfouled UC 020 membrane

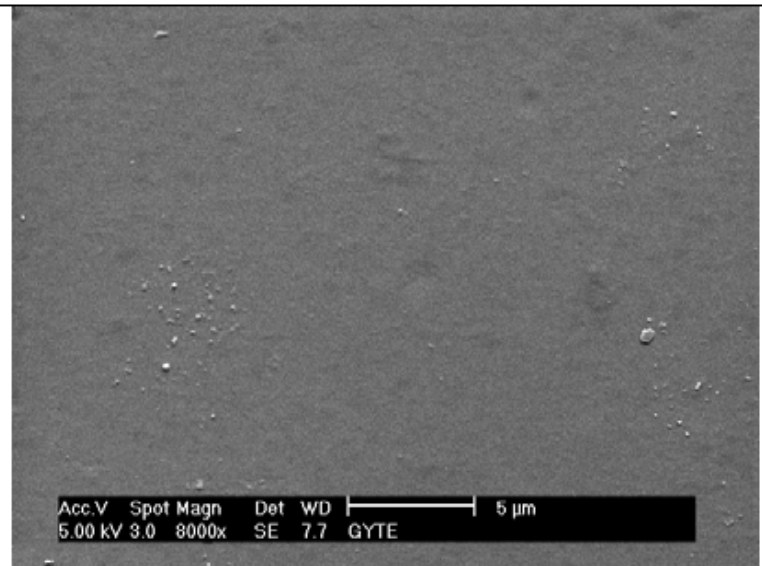

(g) Fouled UC 005 membrane

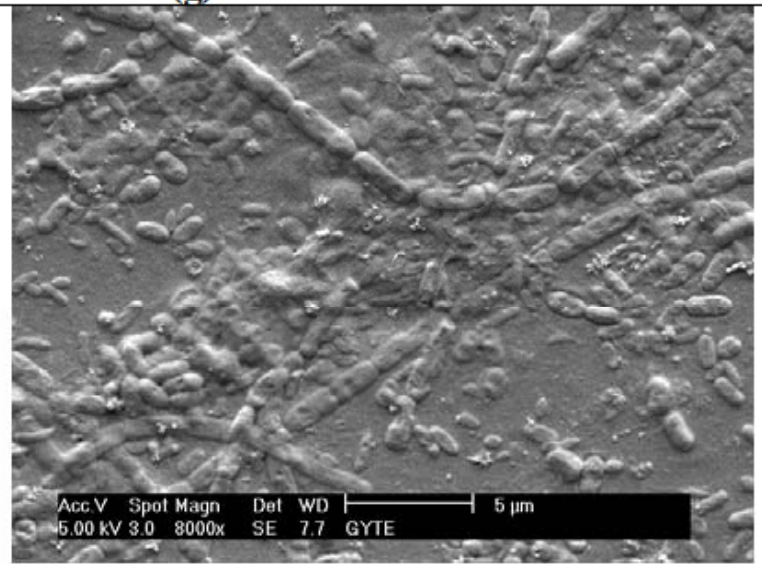

(h) Fouled UC 010 membrane

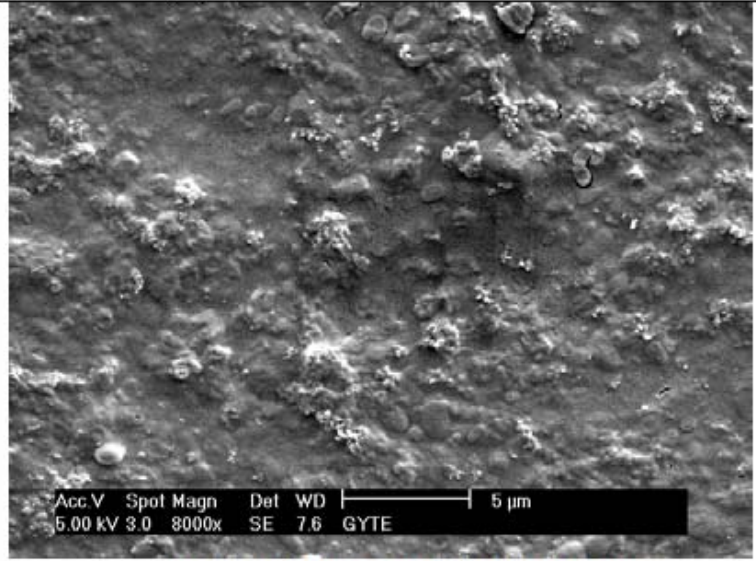

(i) Fouled UC 020 membrane 
(Figure 4). Continued.

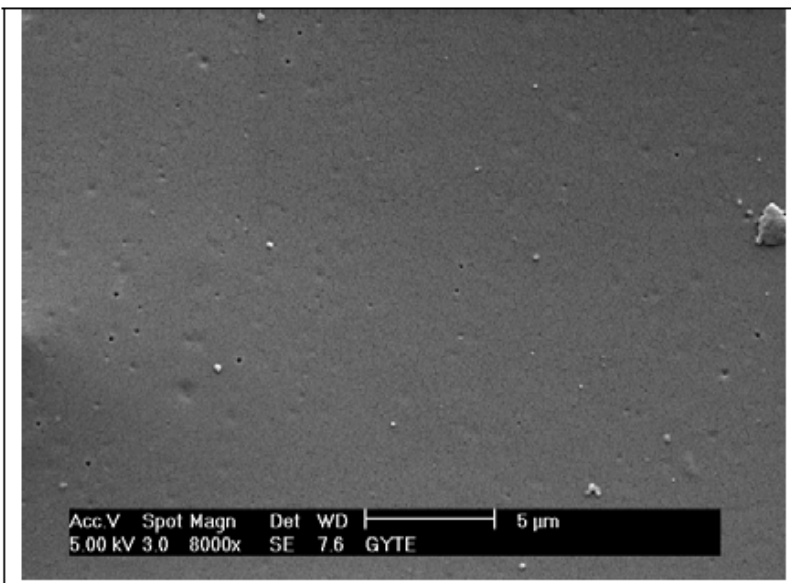

(d) Unfouled UP 005 membrane

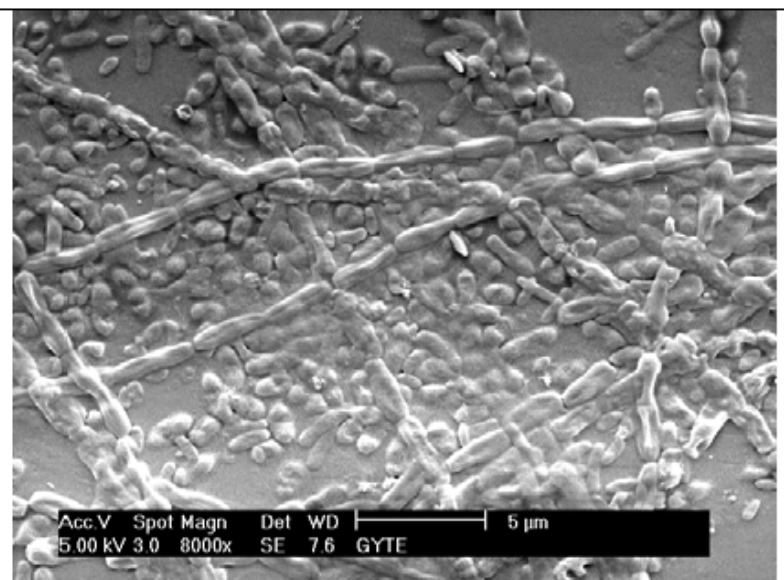

(j) Fouled UP 005 membrane

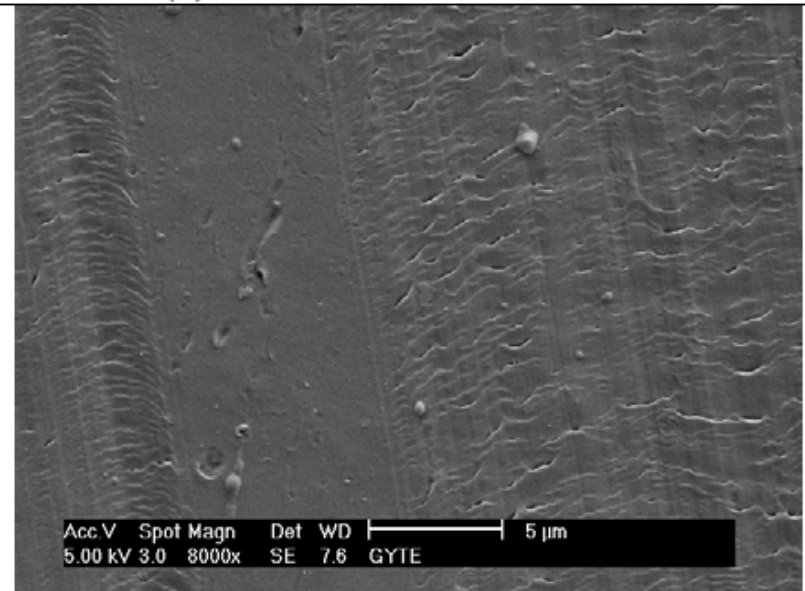

(e) Unfouled UP 010 membrane

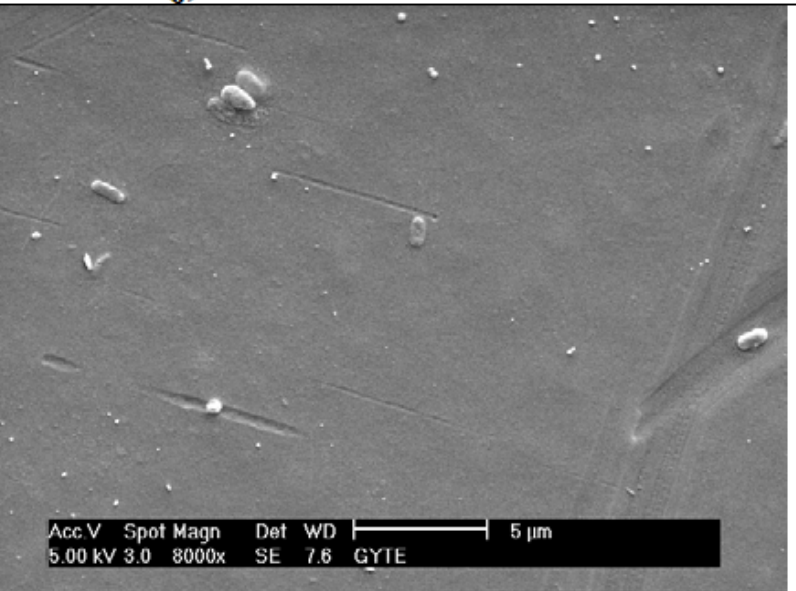

(k) Fouled UP 010 membrane

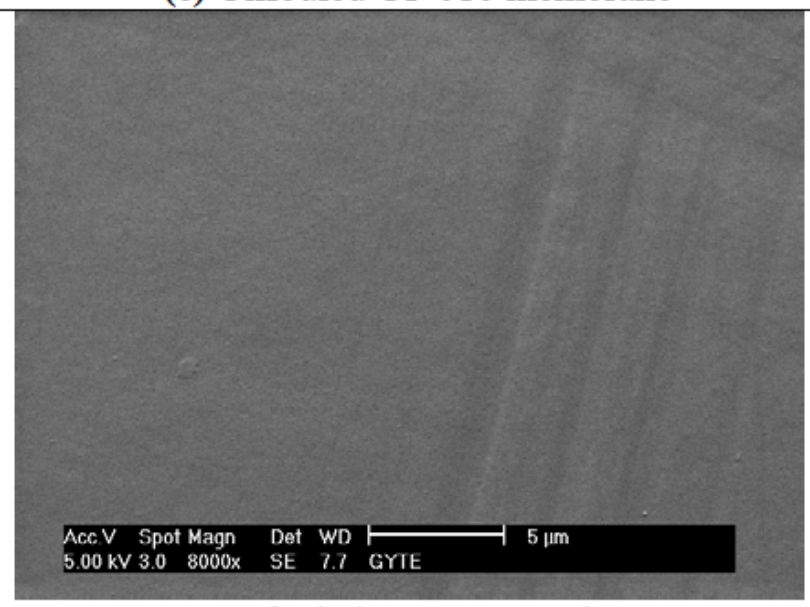

(f) Unfouled UP 020 membrane

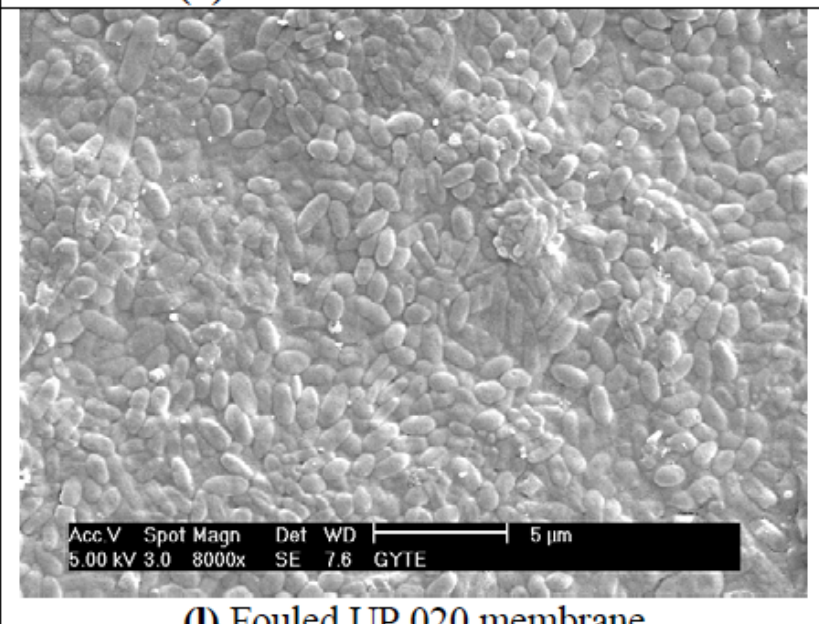

(I) Fouled UP 020 membrane

Figure 4: SEM images of unfouled (a-f) and fouled (g-I) UF membranes.

The SEM images of unfouled (Figure 4a-f) and fouled (Figure $\mathbf{4 g}-\mathrm{I}$ ) UC and UP membranes which belongs to submerged membrane process are shown in Figure 4a-I. The used membranes has a well defined layer of microorganisms accumulated on the surface (Figure $\mathbf{4 g}-\mathbf{I}$ ). The membrane fouling can be explained due to the formation of the gel layer which is caused by deposition of floc forming bacteria on the membranes and results into significant flux reduction [30].

\section{CONCLUSIONS}

A laboratory scale MBR was used to investigate the performance of submerged UF membrane for removing 
of soluble microbial products (SMP) (as proteins and carbohydrates) and fouling mechanisms. The COD concentration of the filtrates from both the UC and UP membranes showed a direct correlation with increasing MWCO. There was no significant difference in the total SMP removal effectives for both the cellulose (UC) and polyethersulphone (UP) membranes with different MWCO characteristics. However, UP membranes were relatively more effective in removing soluble carbohydrates, while UC membranes were more effective in removing soluble proteins. Analysis of the membrane performance data by resistances-in-series model indicated that cake fouling was the dominant membrane fouling mechanisms. Morphological examination of the membranes by SEM and AFM showed significant accumulation of microorganisms on the membrane surface.

\section{ACKNOWLEDGEMENT}

This study was financially supported by the TUBITAK, the Scientific and Technological Research Council of Turkey (Project No: 108Y129).

\section{REFERENCES}

[1] Massé A, Spérandio M, Cabassud C. Comparison of sludge characteristics and performance of a submerged membrane bioreactor and an activated sludge process at high solids retention time. Water Res 2006; 40: 2405-15. http://dx.doi.org/10.1016/j.watres.2006.04.015

[2] Rosenberger S, Kraume M. Filterability of activated sludge in membrane bioreactors. Desalination 2002; 151: 195-200. http://dx.doi.org/10.1016/S0011-9164(02)00998-0

[3] Nagaoka H, Ueda S, Miya A. Influence of extracellular polymers on the membrane separation activated sludge process. Water Sci Technol 1996; 34: 165-72. http://dx.doi.org/10.1016/S0273-1223(96)00800-1

[4] Chang IS, Lee $\mathrm{CH}$. Membrane filtration characteristics in membrane coupled activated sludge system-effect of physiological states of activated sludge on membrane fouling. Desalination 1998; 120: 221-33. http://dx.doi.org/10.1016/S0011-9164(98)00220-3

[5] Nagaoka H, Yamanishi S, Miya A. Modeling of biofouling by extracellular polymers in a membrane separation activated sludge. Water Sci Technol 1998; 38: 497-504. http://dx.doi.org/10.1016/S0273-1223(98)00550-2

[6] Lee W, Kang S, Shin H. Sludge characteristics and their contribution to microfiltration in submerged membrane bioreactors. J Membr Sci 2003; 216: 217-27. http://dx.doi.org/10.1016/S0376-7388(03)00073-5

[7] Zhang B, Yamamoto K. Seasonal change of microbial population and activities in a building wastewater reuse system using a membrane separation activated sludge process. Water Sci Technol 1996; 34: 295-302. http://dx.doi.org/10.1016/0273-1223(96)00658-0

[8] Huang X, Liu R, Qian Y. Behaviour of soluble microbial products in a membrane bioreactor. Process Biochem 2000; 36: 401-406.

http://dx.doi.org/10.1016/S0032-9592(00)00206-5
[9] Tansel B, Sager J, Garland J, Xu S, Levine L, Bisbee P. Biofouling affinity of membrane surfaces under quiescent conditions. Desalination 2008; 227: 264-73. http://dx.doi.org/10.1016/i.desal.2007.06.030

[10] Tansel B, Sager J, Garland J, Xu S, Levine L, Bisbee P. Deposition of extracellular polymeric substances (EPS) and microtopographical changes on membrane surfaces during intermittent filtration conditions. J Membr Sci 2006; 285: 22531. http://dx.doi.org/10.1016/j.memsci.2006.08.031

[11] Tiana JY, Lianga H, Nana J, Yang YL, You SJ, Li GB. Submerged membrane bioreactor (sMBR) for the treatment of contaminated raw water. Chem Eng J 2009; 148: 296-305. http://dx.doi.org/10.1016/..cej.2008.08.032

[12] Choi JH, Ng HY. Effect of membrane type and material on performance of a submerged membrane bioreactor. Chemosphere 2008; 71: 853-59. http://dx.doi.org/10.1016/j.chemosphere.2007.11.029

[13] Yang W, Cicek N, Ilg J. State-of-the-art of membrane bioreactors: Worldwide research and commercial applications in North America. J Membr Sci 2006; 270: 20111.

http://dx.doi.org/10.1016/j.memsci.2005.07.010

[14] Shon HK, Vigneswaran S, Kim S, Cho J, Ngo HH. Effect of pretreatment on the fouling of membranes: application in biologically treated sewage effluent. J Membr Sci 2004; 234: 111-20.

http://dx.doi.org/10.1016/j.memsci.2004.01.015

[15] Haberkamp J, Ruhi AS, Ernst M, Jekel M. Impact of coagulation and adsorption on DOC fractions of secondary effluent and resulting fouling behaviour in ultrafiltration. Water Res 2007; 41: 3794-802.

http://dx.doi.org/10.1016/j.watres.2007.05.029

[16] Wang XD, Wang L, Liu Y, Duan W. Ozonation pretreatment for ultrafiltration of the secondary effluent. J Membr Sci 2007; 287: 187-91.

http://dx.doi.org/10.1016/j.memsci.2006.10.016

[17] Basar CA, Karagunduz A, Cakici A, Keskinler B. Removal of surfactants by powered activated carbon and microfiltration. Water Res 2004; 38: 2117-24.

http://dx.doi.org/10.1016/j.watres.2004.02.001

[18] Keskinler B, Yildiz E, Erhan E, Dogru M, Bayhan YK, Akay G. Crossflow microfiltration of low concentration-nonliving yeast suspensions. J Membr Sci 2004; 233: 59-69. http://dx.doi.org/10.1016/i.memsci.2003.12.014

[19] Danis U, Keskinler B. Chromate removal from wastewater using micellar enhanced crossflow filtration: Effect of transmembrane pressure and crossflow velocity. Desalination 2009; 249: 1356-64. http://dx.doi.org/10.1016/i.desal.2009.06.023

[20] Dizge N, Koseoglu-Imer DY, Karagunduz A, Keskinler B. Effect of sludge retention time on membrane bio-fouling using different type and pore size of membranes in a submerged membrane bioreactor. Water Sci Tech 2013; 67(3): 604-11.

http://dx.doi.org/10.2166/wst.2012.607

[21] Dizge N, Koseoglu-Imer DY, Karagunduz A, Keskinler B. Effects of cationic polyelectrolyte on filterability and fouling reduction of submerged membrane bioreactor (MBR). J Membr Sci 2011; 377: 175-81. http://dx.doi.org/10.1016/..memsci.2011.04.048

[22] APHA-AWWA-WEF, Standard methods for examination of water and wastewater, 20th ed. APHA, AWWA, and WEF, Washington, DC 1998.

[23] Li T, Bai R, Liu J. Distribution and composition of extracellular polymeric substances in membrane-aerated biofilm. J Biotech 2008; 135: 52-57. http://dx.doi.org/10.1016/j.jbiotec.2008.02.011 
[24] Lowry $\mathrm{OH}$, Rosebrough NJ, Farr AL, Randall RJ. Protein measurement with the folin phenol reagent. J Biol Chem 1951; 193: 265-75.

[25] Dubois MJ, Gills KA, Hamilton JK, Reber PA, Smith F. Colorimetric method for determination of sugars and related substances. Anal Chem 1956; 28: 350-56. http://dx.doi.org/10.1021/ac60111a017

[26] Wang P, Wang Z, Wu Z, Mai S. Fouling behaviours of two membranes in a submerged membrane bioreactor for municipal wastewater treatment. J Membr Sci 2011; 382: 6069. http://dx.doi.org/10.1016/j.memsci.2011.07.044

[27] Kaya Y, Ersan G, Vergili I, Gönder ZB, Yilmaz G, Dizge N, Aydiner $\mathrm{C}$. The treatment of pharmaceutical wastewater using in a submerged membrane bioreactor under different sludge retention times. J Membr Sci 2013; 442: 72-82. http://dx.doi.org/10.1016/j.memsci.2013.03.059

[28] Wei CH, Huang X, Aim RB, Yamamoto K, Amy G. Critical flux and chemical cleaning-in-place during the longterm operation of a pilot-scale submerged membrane bioreactor for municipal wastewater treatment. Water Res 2011; 45: 863-71.

http://dx.doi.org/10.1016/j.watres.2010.09.021

[29] Wang P, Wang Z, Wu Z, Mai S. Fouling behaviours of two membranes in a submerged membrane bioreactor for municipal wastewater treatment. J Membr Sci 2011; 382: 6069.

http://dx.doi.org/10.1016/j.memsci.2011.07.044

[30] Zhang G, Ji S, Gao X, Liu Z. Adsorptive fouling of extracellular polymeric substances with polymeric ultrafiltration membranes. J Membr Sci 2008; 309: 28-35. http://dx.doi.org/10.1016/j.memsci.2007.10.012

[31] Zhu LP, Zhang XX, Xu L, Du CH, Zhu BK, Xu YY. Impoved protein-adsorption resistance of polyethersulfone membranes via surface segregation of ultrahigh molecular weight poly(styrene-alt-maleic anhydride). Col Surf B Biointerf 2007; 57: 189-97.

http://dx.doi.org/10.1016/j.colsurfb.2007.01.021 